\title{
STUDI PENGARUH LAJU ALIRAN UDARA PENDINGIN PADA KONDENSATOR TERHADAP DISTRIBUSI SUHU MODEL LOOP HEAT PIPE
}

\author{
Rifa Reynaldi ${ }^{1}$, Mukhsinun Hadi Kusuma ${ }^{2 *}$, Giarno ${ }^{2}$, Dyah Arum Wulandari ${ }^{1}$ \\ ${ }^{1}$ Pendidikan Teknik Mesin Universitas Negeri Jakarta, Jl Rawamangun Muka Raya, Jakarta \\ 13220 \\ ${ }^{2}$ Pusat Teknologi dan Keselamatan Reaktor Nuklir, Badan Tenaga Nuklir Nasional ( BATAN), \\ Kawasan Puspitek Serpong, Tangerang Selatan 15314 \\ *Email : luluikal@ batan.go.id
}

\begin{abstract}
ABSTRAK
STUDI PENGARUH LAJU ALIRAN UDARA PENDINGIN PADA KONDENSER TERHADAP DISTRIBUSI SUHU MODEL LOOP HEAT PIPE. Penggunaan sistem pendingin pasif perlu ditingkatkan dalam rangka meningkatkan keselamatan operasi instalasi nuklir. Salah satu teknologi sistem pendingin pasif yang berpotensi untuk digunakan adalah loop heat pipe (LHP), atau biasa disebut dengan pipa kalor melingkar. Tujuan studi eksperimen ini adalah mempelajari pengaruh besarnya laju aliran udara pendingin terhadap pembuangan kalor oleh model LHP, dan mempelajari fenomena perpindahan kalor yang terjadi di dalamnya. Dalam studi ini dilakukan eksperimen dengan mengoperasikan model LHP pada berbagai variasi laju aliran pendinginan udara sebesar $0 \mathrm{~m} / \mathrm{s}, 1 \mathrm{~m} / \mathrm{s}, 1,5 \mathrm{~m} / \mathrm{s}$ dan $2 \mathrm{~m} / \mathrm{s}$. Pemberian beban kalor pada bagian penguapan dengan melakukan variasi suhu air panas pada $35^{\circ} \mathrm{C}, 45^{\circ} \mathrm{C}, 55^{\circ} \mathrm{C}$, dan $65^{\circ} \mathrm{C}$. Model LHP diisi dengan fluida kerja berupa air demineral pada rasio pengisian $200 \%$. Model LHP divakum dengan tekanan awal $-74 \mathrm{~cm} \mathrm{Hg}$. Hasil studi menunjukkan bahwa model LHP memiliki hambatan termal terendah sebesar $0,0017{ }^{\circ} \mathrm{C} / \mathrm{W}$ pada saat diberikan laju aliran pendingin $2 \mathrm{~m} / \mathrm{s}$. Kesimpulan studi menyebutkan bahwa semakin besar laju aliran pendingin di kondensator dapat meningkatkan unjuk kerja termal model LHP.

Kata kunci: laju aliran pendingin, pipa kalor melingkar, sistem pendingin pasif, instalasi nuklir.
\end{abstract}

\begin{abstract}
STUDY ON THE EFFECT OF COOLING AIRFLOW ON CONDENSOR TO TEMPERATURE DISTRIBUTION LOOP HEAT PIPE MODEL. The use of passive cooling systems needs to be increased to improve the safety of nuclear installation operations. One of the passive cooling system technologies that have the potential to be used is the loop heat pipe (LHP). The purpose of this experimental study is to study the effect of the magnitude of the cooling airflow rate on heat dissipation by the LHP model and study the heat transfer phenomenon that occurs in it. In this study, an experiment was carried out by operating the LHP model at various variations in the cooling airflow rate of $0 \mathrm{~m} / \mathrm{s}, 1 \mathrm{~m} / \mathrm{s}, 1.5 \mathrm{~m} / \mathrm{s}$, and $2 \mathrm{~m} / \mathrm{s}$. Giving heat to the evaporator is used by varying the temperature of hot water at $35^{\circ} \mathrm{C}, 45^{\circ} \mathrm{C}$, $55^{\circ} \mathrm{C}$, and $65^{\circ} \mathrm{C}$. The LHP model is filled with a working fluid in the form of demineralized water at a $200 \%$ filling ratio. The LHP model is vacuumed with an initial pressure of $-74 \mathrm{~cm} \mathrm{Hg}$. The results of the study show that the LHP model has the lowest thermal resistance of $0.0017^{\circ} \mathrm{C} / \mathrm{W}$ when given a coolant flow rate of $2 \mathrm{~m} / \mathrm{s}$. The conclusion of the study states that the greater the coolant flow rate in the condenser can increase the thermal performance of the LHP model.

Keywords: coolant flowrate, loop heat pipe, passive cooling system, nuclear installation
\end{abstract}




\section{PENDAHULUAN}

Dalam upaya meningkatkan keselamatan pada sistem pendingin di instalasi nuklir, para peneliti di seluruh dunia mengembangkan teknologi sistem pendingin pasif (passive cooling system) yang dapat membantu mendinginkan reaktor, akibat panas peluruhan (decay heat) karena sistem pendingin aktif tidak dapat beroperasi. Konsep dari sistem keselamatan pasif adalah pembuang kalor cadangan yang dapat tetap bekerja walaupun sistem pendingin utamanya dalam keadaan tidak aktif, tanpa memerlukan sumber energi penggerak dari luar. Maka untuk meningkatkan keselamatan maka sistem pendingin pasif perlu diaplikasikan pada PLTN [1]. Salah satu sistem pendingin pasif yang memiliki potensi untuk digunakan pada instalasi nuklir adalah loop heat pipe (LHP), atau biasa disebut dengan pipa kalor melingkar.

LHP merupakan salah satu sistem pendingin pasif yang dapat digunakan untuk membuang sebagian kalor sisa yang dihasilkan oleh instalasi nuklir pada kondisi normal ataupun pada saat mengalami kecelakaan hingga tidak adanya energi listrik untuk mengaktifkan sistem pendingin utama. Loop heat pipe memiliki kemampuan pembuangan kalor yang baik dan dapat digunakan untuk mempertahankan suhu operasi sehingga tidak terjadi panas berlebih. Y. Maydanik dalam penelitiannya melakukan eksperimen dengan banyak jenis LHP. Ia menyimpulkan LHP merupakan alat yang sangat efisien untuk membuang kalor [2]. S. Wang et al. mempelajari fenomena start-up dan kinerja kondisi tunak dari miniatur LHP. Metode yang digunakan yaitu menguji 3 buah miniatur LHP dengan ketebalan kapiler yang berbeda yaitu $3 \mathrm{~mm}$, $5 \mathrm{~mm}$, dan $7 \mathrm{~mm}$. Menyimpulkan bahwa dengan bertambahnya ketebalan lapisan kapiler, LHP memiliki startup yang lebih baik daya rendah [3]. T. Shioga et al. melakukan penelitian untuk mencari karakteristik ultrathin LHP. Metode yang dilakukan yaitu memvariasikan interlayer pada bagian penguapan dengan 4 tipe yang berbeda yang diberi nama $Z_{1}, Z_{2}, Z_{3}$, dan $Z_{4}$. Hasil dalam penelitian tersebut merekomendasikan ultrathin LHP sebagai sistem pendingin pasif pada elektronik [4]. Ramasamy, N.S et al. melakukan penelitian dengan melakukan pengujian pada miniatur LHP. Metode yang dilakukan adalah memberikan variasi pada beban kalor yang berbeda. Hasil dalam penelitian ini merekomendasikan miniatur LHP untuk diaplikasikan pada alat yang membutuhkan manajemen termal yang andal hingga $200 \mathrm{~W}$ [5]. Zhou, G et al. pada penelitiannya mempelajari modul pendingin udara aktif yang didasarkan pada ultrathin LHP dengan ketebalan $1 \mathrm{~mm}$. Metode yang digunakan yaitu dengan memvariasikan konveksi udara alami dan konveksi udara paksa. Hasil dari 
penelitian ini merekomendasikan miniatur LHP dengan modul pendingin sebagai keandalan stabilitas dan efsiensi sistem pendingin [6]. Anand, A.R. et al. melakukan studi eksperimental untuk mempelajari karakteristik termal dari miniatur LHP. Pengujian dilakukan dengan 4 fluida kerja yaitu aseton, methanol, pentana dan etanol pada dua suhu penyerap yang berbeda. Hasil penelitian menyebutkan bahwa methanol memiliki batas deprime tertinggi (yaitu batas kapiler dalam LHP) sedangkan pentana memiliki suhu operasi terendah [7]. G. Zhou et al. melakukan identifikasi performa pada miniatur ultrathin LHP untuk diaplikasikan pada mobile electronic. Metode yang digunakan yaitu dengan melakukan simulasi pemanasan keramik untuk mendinginkan 3 buah prosesor yang berbeda. Hasil dari penelitian ini merekomendasikan miniatur ultrathin LHP sebagai solusi pendingin mobile electronics seperti computer tablet dan telepon pintar [8]. Y. Maydanik et al. dalam peneltiannya mengembangkan dan menyelidiki karakteristik termal LHP. Metode yang dilakukan yaitu memvariasikan fluida kerja yang berbeda. Penelitian ini menyimpulkan bahwa amonia merupakan fluida kerja yang paling sesuai pada suhu saturasi dari $40{ }^{\circ} \mathrm{C}$ hingga $60^{\circ} \mathrm{C}$ [9]. Diallo, T.M. et al. melalui penelitiannya dalam membandingkan PVT-LHP modern dengan PVT-LHP konvensional. Menyimpulkan dengan adanya peningkatan suhu udara ambient mengakibatkan terjadinya peningkatan efisiensi termal dan sedikit penurunan pada efisiensi listrik. [10]. He, S. et al. dalam penelitianya menyelidiki kinerja LHP dengan plat bergaris. Hasil dalam penelitian ini menunjukkan bagian penguapan dengan plat beragaris dapat menahan tekanan kerja dengan suhu yang diizinkan untuk operasi normal elektronik [11]. S. Launay et al. melakukan tinjauan pustaka dari berbagai jurnal. Hasil dari tinjauan pustaka tersebut menyimpulkan pemilihan fluida bergantung terhadap tekanan jenuh dan suhu pengoperasian. Pada aplikasi suhu rendah dapat digunakan amonia dan propilena kemudian untuk suhu tinggi dapat digunakan fluida kerja yaitu air, alkohol, aseton, dan R-134A [12].

Berdasarkan studi literatur LHP memiliki potensi sebagai pengambil kalor pada instalasi nuklir. Pada tahun 2017, Kusuma et al. melakukan penelitian mengenai pipa kalor lurus tanpa sumbu kapiler sebagai sistem pendingin pasif pada kolam peyimpanan bahan bakar bekas nuklir. Metode yang dilakukan yaitu dengan memberikan variasi pada rasio pengisian dan beban kalor. Hasil dari penelitian tersebut merekomendasikan pipa kalor dapat dipertimbangkan sebagai sistem pendingin pasif bahan bakar nuklir [1]. Penelitian ini merupakan bagian dari penelitian mengenai penggunaan LHP sebagai sistem pendingin 
pasif pada instalasi nuklir yang sedang dilakukan oleh Pusat Teknologi Keselamatan Reaktor Nuklir (PTKRN), Badan Tenaga Nuklir Nasional (BATAN).

Tujuan dalam studi eksperimen ini adalah mempelajari pengaruh besarnya laju aliran udara pendingin yang dialirkan pada bagian kondensator untuk membantu melepaskan kalor terhadap model LHP dan mempelajari fenomena perpindahan kalor yang terjadi di dalamnya. Metode yang dilakukan adalah mengoperasikan model LHP pada berbagai variasi laju aliran udara pendingin yang dihembuskan menuju sirip pada bagian kondensator dengan kecepatan sebesar $0 \mathrm{~m} / \mathrm{s}, 1 \mathrm{~m} / \mathrm{s}, 1,5 \mathrm{~m} / \mathrm{s}$ dan $2 \mathrm{~m} / \mathrm{s}$. Pemberian beban kalor pada bagian penguapan dilakukan dengan memvariasikan suhu air panas pada $35^{\circ} \mathrm{C}, 45^{\circ} \mathrm{C}, 55^{\circ} \mathrm{C}$ dan $65^{\circ} \mathrm{C}$. LHP diisi dengan fluida kerja yaitu air demineral pada rasio pengisian $200 \%$. Tekanan awal yang diberikan didalam model LHP sebesar $-74 \mathrm{~cm} \mathrm{Hg}$. Diharapkan studi ini memberikan gambaran awal untuk mengembangkan LHP skala besar sebagai sistem pendingin pasif pada instalasi nuklir.

\section{METODOLOGI}

Alur dalam penelitian model LHP dapat dilihat pada diagram alir yang ditunjukan oleh Gambar 1.

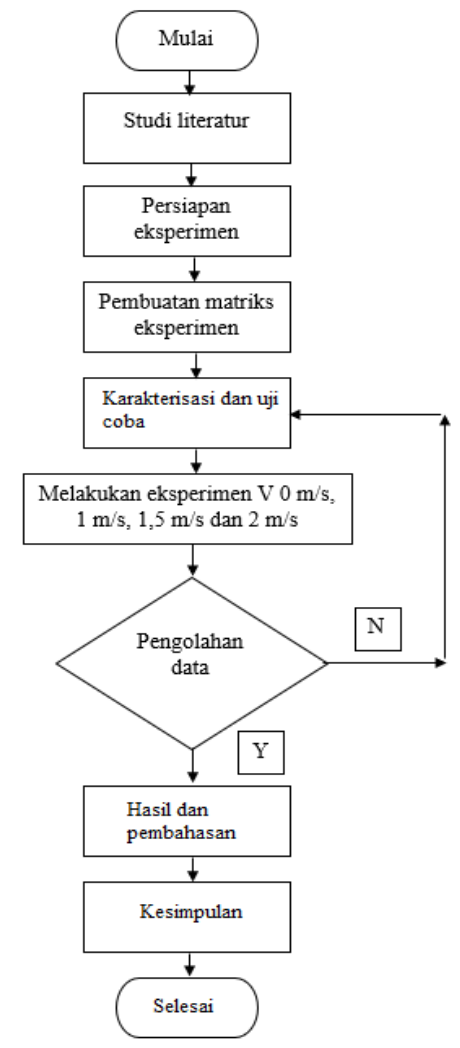

Gambar 1. Diagram alir penelitian

Eksperimen dalam penelitian ini dilakukan untuk menguji untuk kerja termal dari model LHP. Alat ini dibuat dengan material pipa tembaga yang memiliki diameter luar 9,55 $\mathrm{mm}$ dan diameter dalam $8,60 \mathrm{~mm}$. Material tersebut memiliki nilai konduktivias termal $400 \mathrm{~W} / \mathrm{m} . \mathrm{K}$. Pada model LHP dipasang pengukur tekanan untuk mengukur tekanan vakum yang sudah diatur tekanan awalnya sebesar $-74 \mathrm{~cm} \mathrm{Hg}$. Model LHP juga dilengkapi katup untuk memasukkan dan mengeluarkan fluida kerja yang berupa air demineral. Pengukuran suhu dilakukan secara langsung dengan 16 buah termokopel tipe K. Rangkaian peralatan eksperimental yang digunakan dalam penelitian ini ditunjukan pada Gambar 2. 


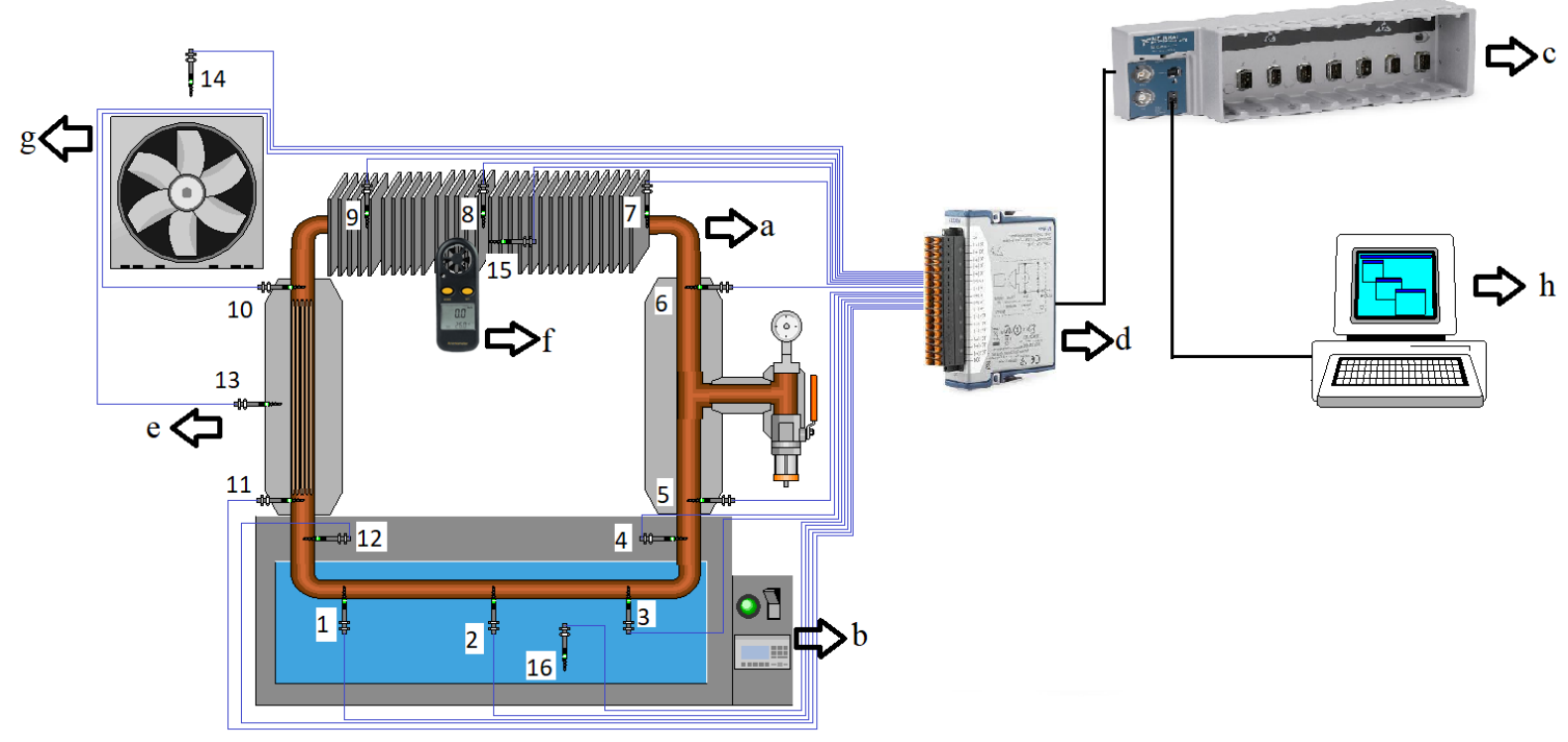

Gambar 2. Rangkaian peralatan eksperimental

Keterangan :

1. Penguapan 1

9. Kondensator 3

2. Penguapan 2

10. Kondensator 4

3. Penguapan 3

11. Kondensator 5

4. Adiabatik 1

12. Kondensator 6

5. Adiabatik 2

13. Isolator

6. Adiabatik 3

14. Udara Ambient

7. Kondensator 1

15. Sirip

Kondensator

8. Kondensator 2 16. Temperatur Air

Dari Gambar 2 terlihat bahwa model LHP memiliki 4 bagian yaitu bagian penguapan, adiabatik, kondensator dan adiabatik dengan sumbu. Bagian penguapan merupakan bagian bawah LHP yang direndam ke dalam air yang dipanaskan oleh circulating thermostatic bath (CTB). Kalor yang ditangkap oleh bagian penguapan memanaskan fluida kerja yakni air demineral yang ada di dalam LHP. Terpasang 3 buah termokopel tipe $\mathrm{K}$ sebagai pengukur suhu untuk bagian penguapan. Bagian adiabatik merupakan jalur sirkulasi uap hasil proses evaporasi dari bagian penguapan ke bagian kondenser. Bagian ini di isolasi menggunakan glass wool yang dipasang secara melingkar dan ditutup menggunakan tabung isolator pada bagian luarnya agar kalor tidak lepas ke lingkungan. Pada bagian ini dipasangkan 3 buah termokopel tipe $\mathrm{K}$ sebagai pengukur suhu untuk bagian adiabatik. Bagian kondensator dipasang sirip sebanyak 50 buah sepanjang bagian kondensator untuk membantu membuang kalor ke lingungan. Sirip yang digunakan pada bagian ini menggunakan material aluminium yang berukuran $120 \mathrm{~mm}$ $\times 50 \mathrm{~mm}$. Diletakan 3 buah termokopel pada bagian kondensator dan 1 buah termokopel 
pada bagian sirip. Bagian adiabatik dengan sumbu diletakan 16 pipa kapiler dengan panjang $200 \mathrm{~mm}$ dengan diameter dalam 0,5 $\mathrm{mm}$ dan diameter luar $1,8 \mathrm{~mm}$ untuk mencegah uap panas pada bagian penguapan untuk mengalir melalui kedua saluran adiabatik. Pada bagian adiabatik dengan sumbu dipasang 3 buah termokopel sebagai pengukur suhu. Termokopel diletakan pada air didalam CTB, Isolasi, dan juga dinding untuk mengukur suhu ruangan. Perekaman data eksperimen dilakukan menggunakan perangkat lunak LabVIEW. Kecepatan udara pendingin yang divariasikan dilakukan dengan memberikan jarak antara kipas dan kondensator dengan kecepatan udara pendingin $0 \mathrm{~m} / \mathrm{s} ; 1 \mathrm{~m} / \mathrm{s} ; 1,5 \mathrm{~m} / \mathrm{s}$, dan $2 \mathrm{~m} / \mathrm{s}$. Pengukuran kecepatan udara dilakukan dengan anemometer. Dasar pemilihan variasi kecepatan udara pendingin dikarenakan mendekati nilai rata rata kecepatan angin yang ada di Indonesia yakni berkisar 2,4 m/s [13]. Matriks eksperimen yang digunakan dalam eksperimen ini ditunjukan oleh Tabel 1.
Tabel 1. Matriks Eksperimen

\begin{tabular}{|c|c|c|c|c|}
\hline $\begin{array}{c}\text { Fluida } \\
\text { Kerja }\end{array}$ & $\begin{array}{c}\text { Rasio } \\
\text { pengisian } \\
(\%)\end{array}$ & $\begin{array}{l}\text { Laju aliran } \\
\text { udara } \\
\text { pendingin } \\
(\mathrm{m} / \mathrm{s})\end{array}$ & $\begin{array}{l}\text { Suhu } \\
\text { CTB } \\
\left({ }^{\circ} \mathrm{C}\right)\end{array}$ & $\begin{array}{l}\text { Tekanan } \\
(\mathrm{cm} \mathrm{Hg})\end{array}$ \\
\hline \multirow{16}{*}{$\begin{array}{c}\text { Air } \\
\text { Demineral }\end{array}$} & \multirow{16}{*}{200} & 0 & 35 & \multirow{16}{*}{-74} \\
\hline & & 0 & 45 & \\
\hline & & 0 & 55 & \\
\hline & & 0 & 65 & \\
\hline & & 1 & 35 & \\
\hline & & 1 & 45 & \\
\hline & & 1 & 55 & \\
\hline & & 1 & 65 & \\
\hline & & 1,5 & 35 & \\
\hline & & 1,5 & 45 & \\
\hline & & 1,5 & 55 & \\
\hline & & 1,5 & 65 & \\
\hline & & 2 & 35 & \\
\hline & & 2 & 45 & \\
\hline & & 2 & 55 & \\
\hline & & 2 & 65 & \\
\hline
\end{tabular}

\section{HASIL DAN PEMBAHASAN}

Distribusi Suhu Sementara Model LHP

Distribusi suhu model LHP pada laju udara pendingin dengan variasi $0 \mathrm{~m} / \mathrm{s} ; 1 \mathrm{~m} / \mathrm{s}$, $1,5 \mathrm{~m} / \mathrm{s}$, dan $2 \mathrm{~m} / \mathrm{s}$ dengan variasi beban kalor $35^{\circ} \mathrm{C}, \quad 45^{\circ} \mathrm{C}, \quad 55^{\circ} \mathrm{C}$, dan $65^{\circ} \mathrm{C}$ ditampilkan pada Gambar 3 sampai dengan Gambar 6. 


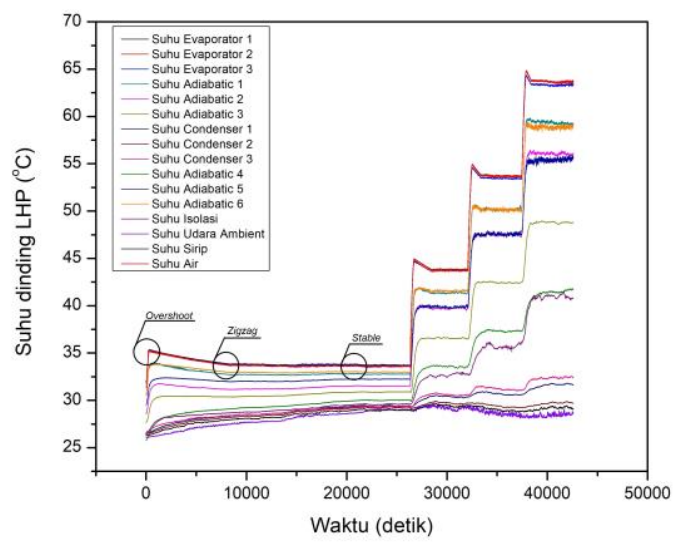

Gambar 3. Distribusi suhu sementara model LHP dengan kecepatan udara pendingin 0 $\mathrm{m} / \mathrm{s}$.

Menurut Gambar 3 pada variasi kecepatan udara pendingin $0 \mathrm{~m} / \mathrm{s}$, pendinginan yang dilakukan oleh model LHP terjadi paling lama dibanding dengan variasi kecepatan udara lainnya. Fenomena melampaui terjadi pada detik ke 0-278, fenomena berliku mulai terjadi pada detik ke 8.500 dan fenomena stabil mulai terjadi pada detik ke 22.000.

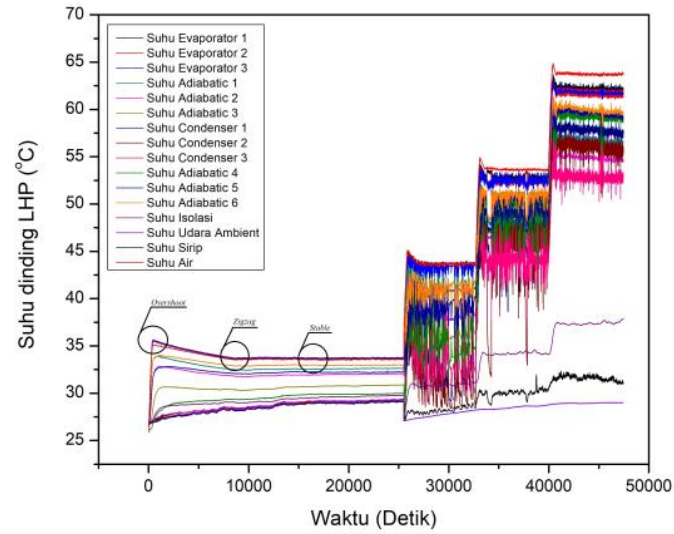

Gambar 4. Distribusi suhu sementara model LHP dengan kecepatan udara pendingin 1 $\mathrm{m} / \mathrm{s}$.

Menurut Gambar 4 pada variasi kecepatan udara pendingin $1 \mathrm{~m} / \mathrm{s}$, pendinginan yang dilakukan oleh model LHP terjadi lebih cepat dibanding dengan variasi kecepatan udara pendinginan $0 \mathrm{~m} / \mathrm{s}$. Hal tersebut dibuktikan dengan fenomena melampaui mulai terjadi pada detik ke 0-388 berliku mulai terjadi pada detik ke 8.300 dan fenomena stabil mulai terjadi pada detik ke 17.400

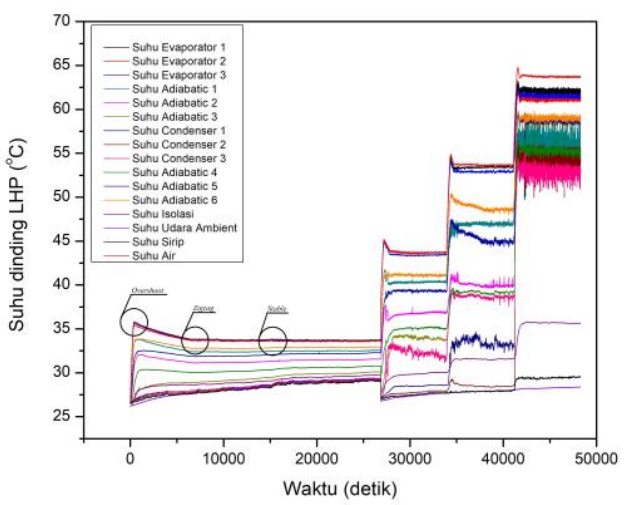

Gambar 5. Distribusi suhu sementara model LHP dengan kecepatan udara pendingin $1,5 \mathrm{~m} / \mathrm{s}$

Menurut Gambar 5 pada variasi kecepatan udara pendingin 1,5 m/s, pendinginan yang dilakukan oleh model LHP terjadi lebih cepat dibanding dengan 2 variasi kecepatan udara sebelumnya. Hal tersebut dibuktikan dengan fenomena melampaui terjadi mulai pada detik ke 0401, fenomena berliku mulai terjadi pada detik ke 6.500 dan fenomena stabil mulai terjadi pada detik ke 15.600 


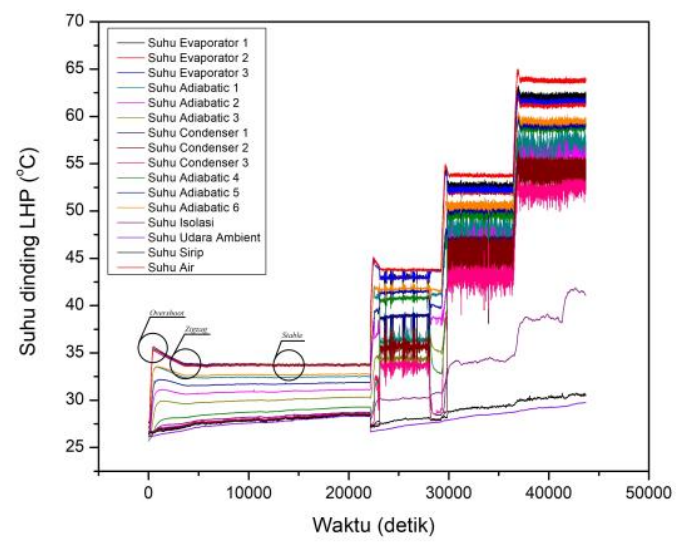

Gambar 6. Distribusi suhu sementara model LHP dengan kecepatan udara pendingin 2 $\mathrm{m} / \mathrm{s}$.

Menurut Gambar 6 pada variasi kecepatan udara pendingin $2 \mathrm{~m} / \mathrm{s}$, pendinginan yang dilakukan oleh model LHP terjadi lebih cepat dibanding dengan semua variasi kecepatan yang ada. Hal tersebut dibuktikan dengan fenomena melampaui mulai terjadi pada detik ke 0-462 fenomena berliku mulai terjadi pada detik ke 3.500 dan fenomena stabil mulai terjadi pada detik ke 14.450.

Dari distribusi suhu sementara pada Gambar 3 sampai dengan Gambar 6 dapat dilihat ada beberapa fenomena yang terjadi di dalam pipa kalor yaitu melampaui, berliku dan stabil. Fenomena melampaui terjadi akibat penguapan fluida kerja pada karena bagian penguapan terus menerima kalor dari sumber air panas pada CTB. Kejadian tersebut mengakibatkan uap air pada bagian penguapan mengalir menuju ke daerah kondensator melalui adiabatik oleh karena itu terjadinya peningkatan suhu LHP. Saat uap air yang sudah berada pada kondensator kalor yang dibawa oleh uap air akan dilepaskan pada bagian kondensator yang mengakibatkan peningkatan suhu pada dinding kondensator. Pelepasan kalor secara konveksi paksa terjadi saat udara yang dialirkan menuju sirip pada kondensator mulai menyebabkan fluida kerja mengalami kondensasi. Ketika fluida kerja mengalami kondensasi, fluida akan turun mengikuti hukum gravitasi melalui bagian adiabatik hingga Kembali menuju bagian penguapan yang menyebabkan terjadinya pola berliku pada distribusi suhu pada dinding LHP. Distribusi suhu dengan pola berliku yang terjadi secara terus menerus terjadi akibat sirkulasi alam mulai berlangsung, namun belum mencapai keadaan yang stabil. Fenomena yang selanjutnya terjadi adalah fenomena stabil, dimana pada kondisi ini distribusi suhu yang terjadi di dalam LHP perlahan menjadi tunak. Keadaan tunak merupakan keadaan suhu tetap terjadi peningkatan dan penurunan dengan nilai yang tidak terlalu signifikan yang terus berlangsung pada beban kalor dan kecepatan udara pendingin yang konstan. Kondisi tersebut juga telah menunjukkan bahwa sirkulasi secara alami antara uap dan kondensat telah terjadi di dalam LHP berlangsung secara kontinu dan stabil.

\section{Unjuk Kerja Termal LHP}

Unjuk kerja LHP merupakan faktor yang sangat penting dalam penilaian kinerja 
model LHP. Unjuk kerja termal dapat diukur dari nilai tahanan termal yang dihasilkan oleh model LHP. Nilai tahanan termal sangat dipengaruhi oleh perbedaan suhu pada bagian penguapan dan kondensator serta besarnya beban kalor yang diterima oleh bagian penguapan sebuah LHP. Kinerja pipa kalor terbaik ditunjukkan oleh semakin kecilnya nilai tahanan termal. Tahanan termal pada pipa kalor dengan variasi kecepatan udara pendingin $0,1,1,5$ dan 2 m/s diperlihatkan oleh Gambar 7.

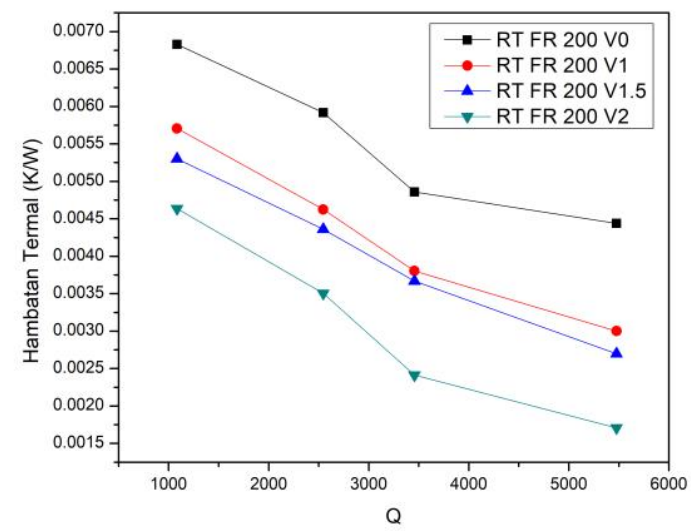

Gambar 7. Hambatan termal model LHP.

Dari Gambar 7 dapat dilihat bahwa unjuk kerja termal terbaik didapatkan saat model LHP dioperasikan dengan kecepatan udara $2 \mathrm{~m} / \mathrm{s}$, dengan nilai hambatan termal 0,0017 ${ }^{\circ} \mathrm{C} / \mathrm{W}$. Hasil yang didapatkan menunjukkan bahwa pada beban kalor yang tetap, semakin tinggi kecepatan udara pendingin yang dialirkan pada bagian kondensator akan menghasilkan rendahnya perbedaan suhu model LHP pada bagian penguapan dan kondensator.
Fenomena yang terjadi pada model LHP terjadi karena kalor pada bagian kondensator dilepas dengan bantuan udara pendingin yang dialirkan pada sirip-sirip pada bagian kondensator. Fenomena pelepasan kalor yang terjadi pada bagian kondensator sebelum dialiri udara pendingin adalah konveksi alami, namun saat siripsirip pada bagian kondensator dialirkan udara pendingin konveksi alami berubah menjadi konveksi paksa.

\section{KESIMPULAN}

Berdasarkan hasil eksperimen dapat disimpulkan bahwa laju aliran udara memiliki pengaruh yang sangat signifikan terhadap unjuk kerja termal model LHP. Nilai hambatan termal terbaik diperoleh pada variasi laju aliran udara pendingin $2 \mathrm{~m} / \mathrm{s}$ dan suhu air panas $65^{\circ} \mathrm{C}$ yakni sebesar 0,0017 ${ }^{\circ} \mathrm{C} / \mathrm{W}$. Semakin besar laju aliran pendingin, maka semakin besar pula unjuk kerja termal model LHP. Hal ini terjadi karena semakin besar laju aliran pendingin, maka semakin banyak kalor yang dapat dilepas ke lingkungan. Fenomena perpindahan kalor yang diperoleh yaitu melampaui, berliku, dan stabil. Fenomena ini memiliki similaritas dengan fenomena pipa kalor pada umumnya.

\section{UCAPAN TERIMA KASIH}

Penelitian ini dapat terlaksana karena adanya dukungan dan bantuan dari berbagai pihak yang terlibat, karena itu penulis 
mengucapkan terima kasih kepada seluruh karyawan dan staf dari Laboratorium Termohidrolika, Pusat Teknologi dan Keselamatan Reaktor Nuklir, yang telah memfasilitasi serta membimbing penulis dalam menyelesaikan penelitian ini.

\section{DAFTAR PUSTAKA}

[1] M. H. Kusuma, "Sistem Pendingin Pasif di Kolam Penyimpanan Bahan Bakar Bekas Nuklir Dengan Menggunakan Pipa Kalor," Universitas Indonesia, 2017.

[2] Y. F. Maydanik, "Loop heat pipes," Appl. Therm. Eng., vol. 25, no. 5-6, pp. 635-657, 2005, doi: 10.1016/j.applthermaleng.2004.07.01 0 .

[3] S. Wang, W. Zhang, X. Zhang, and J. Chen, "Study on start-up characteristics of loop heat pipe under low-power," Int. J. Heat Mass Transf., vol. 54, no. 4, pp. 1002-1007, 2011, doi: 10.1016/j.ijheatmasstransfer.2010.10. 01 .

[4] T. Shioga, Y. Mizuno, and $H$. Nagano, "Operating characteristics of a new ultra-thin loop heat pipe," Int. J. Heat Mass Transf., vol. 151, p. 119436, 2020, doi: 10.1016/j.ijheatmasstransfer.2020.119 436.

[5] N. S. Ramasamy, P. Kumar, B. Wangaskar, S. Khandekar, and Y. F. Maydanik, "Miniature ammonia loop heat pipe for terrestrial applications: Experiments and modeling," Int. J. Therm. Sci., vol. 124, no. October 2017, pp. 263-278, 2018, doi: 10.1016/j.ijthermalsci.2017.10.018.

[6] G. Zhou, J. Li, and Z. Jia, "Powersaving exploration for high-end ultraslim laptop computers with miniature loop heat pipe cooling module," Appl. Energy, vol. 239, no. August 2018, pp. $\quad 859-875, \quad 2019$, doi: 10.1016/j.apenergy.2019.01.258.

[7] A. R. Anand, A. Jaiswal, A. Ambirajan, and P. Dutta, "Experimental studies on a miniature loop heat pipe with flat evaporator with various working fluids," Appl. Therm. Eng., vol. 144, no. August, pp. 495-503, 2018, doi: 10.1016/j.applthermaleng.2018.08.09 2.

[8] G. Zhou, J. Li, and L. Lv, "An ultrathin miniature loop heat pipe cooler for mobile electronics," Appl. Therm. Eng., vol. 109, no. May 2020, pp. 514-523, 2016, doi: 10.1016/j.applthermaleng.2016.08.13 8.

[9] Y. Maydanik, V. Pastukhov, and M. Chernysheva, "Development and investigation of a loop heat pipe with a high heat-transfer capacity," Appl. Therm. Eng., vol. 130, pp. 10521061, 2018, doi: 10.1016/j.applthermaleng.2017.11.08 4.

[10] T. M. O. Diallo et al., "Energy performance analysis of a novel solar PVT loop heat pipe employing a microchannel heat pipe evaporator and a PCM triple heat exchanger," Energy, vol. 167, pp. 866-888, 2019, doi: 10.1016/j.energy.2018.10.192.

[11] S. He, J. Zhao, Z. chun Liu, W. Tian, J. guo Yang, and W. Liu, "Experimental investigation of loop heat pipe with a large squared evaporator for cooling electronics," Appl. Therm. Eng., vol. 144, pp. 383391, 2018, doi: 10.1016/j.applthermaleng.2018.08.07 5.

[12] S. Launay, V. Sartre, and J. Bonjour, "Parametric analysis of loop heat pipe operation: a literature review," Int. J. Therm. Sci., vol. 46, no. 7, pp. 621636, 2007, doi: 10.1016/j.ijthermalsci.2006.11.007.

[13] BPS, "Tekanan Udara dan Penyinaran Matahari di Stasiun Pengamatan BMKG, 2003-2012,” 2015. http://www.bps.go.id/linkTabelStatis/ 
view/id/1350. 